\title{
The impact of SFAS 157 on fair value accounting and future bank performance
}

\author{
Dimu Ehalaiye* \\ School of Accountancy, \\ Massey University, \\ Palmerston North, New Zealand. \\ o.ehalaiye@massey.ac.nz \\ Mark Tippett \\ Business School, \\ University of Sydney, \\ Sydney, Australia \\ M.Tippett@lboro.ac.uk
}

\author{
Tony van Zijl \\ School of Accounting and Commercial Law, \\ Victoria University of Wellington, \\ Wellington, New Zealand. \\ tony.vanzijl@vuw.ac.nz
}

Accepted manuscript. Please cite this article as:

Ehalaiye, D., Tippett, M. and van Zijl, T. (2020), "The impact of SFAS 157 on fair value accounting and future bank performance", International Journal of Accounting \& Information Management, Vol. 28 No. 4, pp. 739-757. https://doi.org/10.1108/IJAIM$\underline{11-2019-0135}$

* Corresponding Author. Address for Correspondence: School of Accountancy, Massey Business School, Massey University, Tennent Drive. Palmerston North 4474, New Zealand. Email: o.ehalaiye@massey.ac.nz 


\title{
The impact of SFAS 157 on fair value accounting and future bank performance
}

\begin{abstract}
Purpose:

We use quarterly financial data on US banks to investigate whether levels-classified fair values based on SFAS 157: Fair Value Measurements, as recognised in the financial statements of the banks over the period from 2008 until 2015, have predictive value in relation to the banks' future financial performance measured by operating cash flows and earnings over a threequarter horizon period. In addition, we consider whether the global financial crisis (GFC) impacted the relationship between SFAS 157 based levels-classified fair values and bank future financial performance.
\end{abstract}

\section{Design/methodology/approach:}

We develop hypotheses connecting the net levels-classified bank fair values based on SFAS 157 with banks' future financial performance. We test the hypotheses by estimating threeperiod quarters' ahead forecasting models. We also use these models to test for the impact of the GFC on the relationship between the fair values and future financial performance.

\section{Findings:}

Our findings suggest that the levels-classified net fair values based on SFAS 157 have predictive value in relation to future cash flows for banks. There is significant variation, across the levels, in the predictive value of levels-classified net fair values for future performance. Our findings indicate that the GFC has limited impact on the predictive value for cash flows 
but the GFC had a significant adverse impact on earnings and, with allowance for the effect of the GFC, the level 2 net fair values have predictive value for the future earnings.

\section{Originality/value:}

The study provides the first direct empirical evidence on the relationship between the SFAS 157 levels-classified quarterly bank fair values recognised in publicly available financial statements and banks' future performance. Our results are consistent with the findings from earlier research (Ehalaiye et al, 2017) using annual data disclosed in the supplementary notes to the financial statements of US banks based on SFAS 107. The study makes a significant contribution to the question of frequency of reporting and to the disclosure vs recognition debate. The study has implications for policy makers, regulators and accounting standards setters such as the Securities and Exchange Commission (SEC) and the FASB in evaluating the use of fair value measurement in financial reporting.

Keywords: Fair Value Accounting, Predictive Value, Operating Earnings, Operating Cash flows.

JEL Classification: G21 G28 M41 


\section{Introduction}

We investigate whether levels-classified net fair values of assets, based on SFAS 157: Fair Value Measurements (hereafter SFAS 157), as recognised in the quarterly financial statements of US banks over the period from 2008 until 2015, have predictive value for banks' future financial performance. This is a significant issue because the Financial Accounting Standards Board (FASB) Conceptual Framework identifies the predictive value of financial information as a relevant metric for the potential inclusion of financial information in firms' publicly available financial statements (FASB, 2010). We also use the global financial crisis (GFC) years of 2008-2009, which coincided with the implementation of the SFAS 157, to determine the extent to which levels-classified fair values have predictive value in a period of extreme market illiquidity and uncertainty.

Prior to 2008 US banks were required only to disclose the fair value of financial instruments in the supplementary notes to the financial statements. However, from 2008 the requirement has been for recognition of these instruments in the financial statements at fair value and disaggregated according to the three levels of estimation of fair value set out in SFAS 157. The three levels vary in objectivity, with the most objective approach being for level 1: exit prices in active markets. The less objective approaches are for level 2: exit prices of similar assets and liabilities in active markets, and level 3: model estimation with as much use as possible of market information as the inputs to the estimation. The reporting of this information quickly led to research to assess its impact. Initially, the studies focussed on value relevance for share prices using a model based on Ohlson (1995). For example, Song, Thomas and Han (2010), which used quarterly data on US banks for 2008, found that the value relevance of levels 1 and 2 were similar but greater than for level 3. Similar results were obtained in Goh, $\mathrm{Li}, \mathrm{Ng}$ and Yong, (2015). 
Subsequent studies have focussed on the predictive value of the disaggregated data on fair value for future financial performance. Altamuro and Zhang (2013) found that the fair value of mortgage servicing rights (MSRs) based on managerial inputs (level 3) better reflects the cash flow and risk characteristics of the underlying assets than the fair value of MSRs based on market inputs (level 2) suggesting that managers can use their information advantage to generate higher quality fair value estimates than by using market inputs, particularly where the market for the underlying asset is inactive. Bratten et al. (2016) using a sample of US bank holding companies, found that fair value adjustments included in other comprehensive income (OCI) can predict earnings both 1 and 2 years ahead. Yao et al. (2018), using a sample of annual data on non-US banks, found that the nondiscretionary fair value level 1 assets are positively associated with earnings persistence, whereas the level 2 assets and level 3 assets are not associated with earnings persistence.

The use of fair value ${ }^{1}$ as a basis of accounting measurement came under heavy scrutiny and criticism during the GFC as it was claimed that it worsened the financial crisis due to its negative effect on the net assets of financial institutions, in particular, banks (American Bankers Association, 2008; Wallison, 2008). Ryan (2008:2) remarked that "[i]t almost seems that the credit crunch was sent to serve as SFAS 157's trial by fire". A key issue about the implementation of SFAS $157^{2}$ that has dominated academic debate is whether the net levels-

\footnotetext{
${ }^{1}$ Fair values incorporate market expectations about the future into asset valuations. Thus, there is a strong basis for the expectation that fair values possess predictive value (Barth, 2006). However, fair values can be the outcome of an estimation process, particularly during periods of market illiquidity where obtaining level 1 classified fair values may be difficult. In such circumstances, there will be concerns about the reliability of the fair value estimates summarised in financial statements (Leone, 2008).
}

${ }^{2}$ SFAS 157 (FASB, 2006) prescribes that fair value is the price that would be received from selling an asset (or paid to transfer a liability) in an orderly transaction between market participants at the relevant measurement date. In reality, though, fair value can be challenging to define as many factors come into play in determining exactly what it might mean. In its purest form, assuming a fully efficient, liquid and perfect market, fair value should equal the market (that is, the liquidation) value of an asset or liability (or, in terms of SFAS 157, its level 1 value). However, in the real world, where markets are not completely liquid for many assets and liabilities, fair value as 
classified bank fair values based on SFAS 157 were value-relevant, especially during the GFC period. This concern was strengthened by the argument that during the GFC there was extreme market illiquidity, so much so that it was difficult to apply the most objective approach to the estimation of fair value (level 1). This meant that during the GFC period there was heavy use of the less objective approaches to the estimation of fair value (levels 2 and 3). Hence, following the period of the GFC, estimation of the relative merits of the three levels of fair value measurement became a focus for empirical work. For example, Bratten et al. (2016) found that fair value adjustments recorded in OCI during the 2007-2009 financial crisis predicted future profitability.

In our earlier study, Ehalaiye, Tippett and van Zijl (2017), we used annual data of a sample of US banks over the period 1995 to 2011 to examine the predictive value of net fair values of financial instruments, as disclosed in the notes to the financial statements, for the financial performance of the banks measured by operating cash flows and operating earnings. We found that current fair value disclosures had a strong association with future operating cash flows for one, two and three year ahead horizons. However, we found a weaker association for fair value disclosures and earnings. We also tested the impact of the GFC years and found that the associations for both cash flows and earnings were not affected but while the indicator for the GFC years was not significant for cash flows it was negative and significant for earnings. In this study, we retest these findings to determine if they hold for corresponding data reported quarterly and recognised in the financial statements. The present study, therefore, provides evidence on the question of frequency of reporting and the ongoing debate on disclosure vs recognition. Our study has significant implications for policy makers, regulators and

described by the FASB may have to be estimated from the values of identical or similar assets which are traded in a liquid market (Level 2) or estimated through model-based valuations (Level 3) where the inputs used are based, as far as possible, on relevant market information. 
accounting standards setters such as the Securities and Exchange Commission (SEC), the FASB, and the IASB, in the evaluation of fair value measurement in financial reporting.

We focus on the predictive value of fair value for bank performance as measured by future cash flows and earnings rather than as measured by stock prices as it is commonly recognised that stock prices provide only indirect evidence about the relevance of fair values to investors (Bernard, 1993; Aboody, Barth, and Kasznik, 1999; Evans, Hodder and Hopkins, 2014, Houqe 2018). It requires only limited reflection to recognise that financial statement information is just one of several influences that simultaneously affect stock prices ${ }^{3}$.

The remainder of our paper is organised as follows. Section 2 provides the development of our hypotheses. Section 3 sets out the research design. Section 4 provides the results and, finally, Section 5 provides the discussion and conclusion.

\section{Theoretical Framework and Hypotheses development}

In our earlier study, Ehalaiye et al (2017), we tested our hypotheses by simply assuming the model widely used in the capital markets literature for tests of predictive ability, viz:

$$
Y_{t}=f\left(X_{t-1}, Y_{t-1}, Z\right)
$$

where $Y_{t}$ is the variable of interest, $X_{t-1}$ is the predictor and $Z$ is a vector of controls. In this section, we develop the model for testing this paper's hypotheses. We begin with the basic SFAS 157 definition of fair value, market prices, which thus reflects fair value as being the present value of the expected future cash flows of the given assets and liabilities (Barth,

\footnotetext{
${ }^{3}$ During the GFC for example it was noted that share prices of several firms were influenced not just by their accounting fundamentals, but by the business/economic environment in which they operated. Hence, when markets panicked share prices fell and remained highly volatile, irrespective of the actual earnings and/or cash flow position of the affected firms (Brunnermeier, 2009).
} 
2000:19; Ryan, 2008:12). We follow Modigliani and Miller (1958) in assuming that the market value of the firm is comprised of the market values of its individual assets and its liabilities. Therefore, using the levels-classified fair value hierarchy introduced by SFAS 157, the market value of the firm's equity at time t, $M V E_{t}$, can be stated as follows:

$$
M V E_{t}=\sum_{i=1}^{N_{1}} a 1_{i t} L 1 N F V A_{i t}+\sum_{i=1}^{N_{2}} a 2_{i t} L 2 N F V A_{i t}+\sum_{i=1}^{N_{3}} a 3_{i t} L 3 N F V A_{i t}
$$

where $\sum_{i=1}^{N_{1}} L 1 N F V A_{i t}$ is the net sum of the $N_{l}$ level 1 fair value assets and liabilities at time $t$, $\sum_{i=1}^{N_{2}} L 2 N F V A_{i t}$ is the net sum of the $N_{2}$ level 2 fair value assets and liabilities at time $t$, and $\sum_{i=1}^{N_{3}} L 3 N F V A_{i t}$ is the net sum of the $N_{3}$ level 3 fair value assets and liabilities at time $t$. Finally, $a 1_{i t} a 2_{i t}, a 3_{i t}$, are the valuation coefficients for the levels-classified net fair value assets at each of the three levels, respectively. The FASB introduced the levels classification because it believed there were issues regarding the reliability of some fair value estimates. Hence, one can expect that the valuation coefficients, $a 1_{i t}, a 2_{i t}$ and $a 3_{i t}$, will differ according to the dependability of the underlying fair value estimates. In other words, one would expect level 1 net fair value estimates to have a valuation coefficient close to unity while level 3 net fair value estimates may have a valuation coefficient that is significantly different from unity.

We follow the literature (Ohlson, 1995; Beaver 1998; Penman, 2007) in assuming that the economic value of an equity security is equal to the present value of its expected future cash flows:

$$
M V E_{t}=\sum_{\tau=t+1}^{\infty} \frac{C_{\tau}}{(1+r)^{\tau-t}}
$$

where $C_{\tau}$ is the expected future cash flow generated by the equity investment at time $\tau$ and $r$ is an appropriate risk-adjusted discount rate. Following Beaver (1998: 48-50), we define the 
permanent cash flow, $P_{t+l}$, as the inter-temporally constant cash flow whose present value is equivalent to the present value of the expected cash flows generated from the given equity investment. It then follows that:

$$
M V E_{t}=\sum_{\tau=t+1}^{\infty} \frac{C_{\tau}}{(1+r)^{\tau-t}} \equiv P_{t+1} \sum_{\tau=t+1}^{\infty} \frac{1}{(1+r)^{\tau-t}}=\frac{P_{t+1}}{r}
$$

Furthermore, the cash flow, $C_{t+1}$, can be decomposed into its permanent component, $P_{t+1}$, and a stochastic error term, $\varepsilon_{t+1}$, as follows:

$$
C_{t+1}=P_{t+1}+\varepsilon_{t+1}
$$

Substitution of this result into equation (2) gives:

$$
M V E_{t}=\frac{C_{t+1}-\varepsilon_{t+1}}{r}
$$

Thus:

$$
\frac{C_{t+1}-\varepsilon_{t+1}}{r}=\sum_{i=1}^{N_{1}} a 1_{i t} L 1 N F V A_{i t}+\sum_{i=1}^{N_{2}} a 2_{i t} L 2 N F V A_{i t}+\sum_{i=1}^{N_{3}} a 3_{i t} L 3 N F V A_{i t}
$$

that is:

$$
C_{t+1}=\sum_{i=1}^{N_{1}} r a 1_{i t} L 1 N F V A_{i t}+\sum_{i=1}^{N_{2}} r a 2_{i t} L_{2 N F V A_{i t}}+\sum_{i=1}^{N_{3}} r a 3_{i t} L_{3 N F V A_{i t}}+\varepsilon_{t+1}
$$


Then, redefining the valuation coefficients as $\alpha 1_{i t}=r a 1_{i t}, \alpha 2_{i t}=r a 2_{i t}, \alpha 3_{i t}=r a 3_{i t}$ gives $^{4}$ :

$$
C_{t+1}=\sum_{i=1}^{N_{1}} \alpha 1_{i t} L 1 N F V A_{i t}+\sum_{i=1}^{N_{2}} \alpha 2_{i t} L 2 N F V A_{i t}+\sum_{i=1}^{N_{3}} \alpha 3_{i t} L 3 N F V A_{i t}+\varepsilon_{t+1}
$$

Given that a firm's earnings tend to track a firm's cash flows into the future (Modigliani and Miller, 1961; Kim and Kross, 2005; Dechow et al., 1998) the model can be restated to also apply to earnings as:

$$
O P_{t+1}=\sum_{i=1}^{N_{1}} \gamma 1_{i t} L 1 N F V A_{i t}+\sum_{i=1}^{N_{2}} \gamma 2_{i t} L 2 N F V A_{i t}+\sum_{i=1}^{N_{3}} \gamma 3_{i t} L 3 N F V A_{i t}+\eta_{t+1}
$$

where $O P_{t+1}$ is the firm's earnings for the period from time $t$ until time $(t+1), \gamma 1_{i t}, \gamma z_{i t}, \gamma 3_{i t}$ are valuation coefficients, $\eta_{t+l}$ is a stochastic error term and the other variables have the same meanings attributed to them as in the cash flow equations (4) through (8) above.

Thus, from the above theoretical modelling, reported fair values are expected to have an association with bank future financial performance. However, this relationship can be

${ }^{4}$ This relationship also holds for non-contiguous periods. Note that no-arbitrage requires $M V E_{t}=\frac{M V E_{t+1}}{(1+r)}$. But from equation (5) $M V E_{t+1}=\frac{C_{t+2}-\varepsilon_{t+2}}{r}$. Therefore, substitution then shows that $M V E_{t}=\frac{C_{t+2}-\varepsilon_{t+2}}{r(1+r)}$. Equation (1) can then be used to show that:

$$
C_{t+2}=\sum_{i=1}^{N_{1}} r(1+r) a 1_{i t} L 1 N F V A_{i t}+\sum_{i=1}^{N_{2}} r(1+r) a 2_{i t} L 2 N F V A_{i t}+\sum_{i=1}^{N_{3}} r(1+r) a 3_{i t} L 3 N F V A_{i t}+\varepsilon_{t+2}
$$

Furthermore, no-arbitrage requires $M V E_{t}=\frac{M V E_{t+2}}{(1+r)^{2}}$ and thus:

$$
C_{t+3}=\sum_{i=1}^{N_{1}} r(1+r)^{2} a 1_{i t} L 1 N F V A_{i t}+\sum_{i=1}^{N_{2}} r(1+r)^{2} a 2_{i t} L 2 N F V A_{i t}+\sum_{i=1}^{N_{3}} r(1+r)^{2} a 3_{i t} L 3 N F V A_{i t}+\varepsilon_{t+3}
$$


compromised if banks report fair values that have been incorrectly estimated due to measurement error and/or opportunistic behaviour on the part of firm management (Benston, 2008). In addition, we note that it is likely that the relationship between future earnings and current fair values will be weaker than the relationship between future cash flows and current fair values. This is because of the approximation made in basing equation (9) on earnings tending to track cash flows and, more importantly, a firm's earnings reflect accruals which are more susceptible to managerial manipulation than are cash flows (Shen and Huang, 2011 and Morris, et al., 2016). Thus, we would expect a much tighter relationship between a firm's current fair values and its future operating cash flows, than would be the case for future operating earnings. ${ }^{5}$ We propose the following hypothesis:

H1a: The current quarter's level 1, level 2 and level 3 net fair values of assets of banks are significantly associated with the future quarters' performance of banks as measured by future cash flows and by earnings.

Furthermore, given the findings in the prior literature that level 1 fair values exhibited greater value relevance based on stock prices than level 2 fair values which in turn exhibited greater value relevance than level 3 fair values (Song, et al., 2010; Goh, et al., 2015), we propose the following hypothesis:

H1b: There is significant variation, across the SFAS157 levels, in the predictive value of levelsclassified net fair value assets for the future performance of banks as measured by cash flows and by earnings.

\footnotetext{
${ }^{5}$ Furthermore, this difference in relationship between fair values and future cash flows and earnings could possibly be because, in theoretical terms, fair values represent the expected present value of the future cash flows of the affected assets rather than the expected present value of their earnings (Ryan, 2008).
} 
During financial crises, fair values, even at level 1, may be extremely difficult to obtain, and their reliability compromised where markets become illiquid (Leone, 2008), as was evident during the GFC of 2008-2009. The FASB responded to this concern by clarifying in its staff position papers on SFAS 157 how the fair value of financial assets should be estimated when asset markets are relatively inactive and/or when the level of activity within asset markets has decreased significantly (FASB, 2008; FASB, 2009). The possibility that market illiquidity will have a negative impact on the dependability of the fair value estimates summarised in corporate financial statements will also mean that the relationship between the reported fair values and future cash flows and earnings could be compromised. This, in turn, raises an empirical question as to whether such market illiquidity did have an adverse impact on the relationship between current fair value estimates and future cash flows during the GFC years of 2008-2009. Hence, we test the following hypothesis based on fair values recognised in bank financial statements under SFAS 157:

H2: The global financial crisis had a negative impact on the association between current quarter's level 1, level 2 and level 3 net fair value assets of banks and the future quarters' performance of banks as measured by future cash flows and by earnings.

\section{Research design}

\subsection{Sample data}

The study covers 31 quarterly periods from the first quarter of 2008 until the third quarter of 2015. The starting point of the study reflects the first quarter where SFAS 157 mandated the recognition of levels-classified bank fair values. Following prior studies, we provide for a 1, 2 and 3 quarter ahead forecasting model to empirically evaluate the relationship between current quarter fair values and the future quarters' operating cash flows/earnings (Aboody et al., 1999). 
Thus, in our empirical analysis, every current firm quarter recognised net level asset fair value has corresponding cash flows and earnings information at a minimum of one quarter ahead and up to a maximum of three quarters ahead.

The data for the study was sourced from the COMPUSTAT Bank Fundamentals Quarterly Database for U.S. banks with a minimum size of \$US500 million in total assets as of 2008 . These banks met the SFAS 107 implementation size criterion of \$US500 million in total assets as of year 2008 for financial institutions, which required them to disclose the fair values of their financial assets and liabilities (Eccher et al., 1996). Following Fox (1991), we classified observations with studentized residuals that exceed 3.0 in absolute value as outliers and we exclude these from the regressions. We also exclude banks with missing data for any of the relevant variables. The final sample consists of $13,926(13,963)$ firm-quarter observations for future operating cash flows (future operating earnings) at time $q t+1 ; 13,253(13,317)$ firmquarter observations for future operating cash flows (future operating earnings) at time $q t+2$; and $12,599(12,651)$ firm-quarter observations for future operating cash flows (future operating earnings) at time $q t+3$.

\subsection{Test methodology}

To test our hypotheses $1 \mathrm{a}$ and $1 \mathrm{~b}$, we estimated the following multiple regression model, adapted from the model derived in Section 2:

$$
\begin{aligned}
\operatorname{Perf}_{i q t+\tau}= & a_{0}+a_{1} L_{1 N F V A}+a_{i q t} L 2 N F V A_{i q t}+a_{3} L_{3 N F V A_{i q t}+a_{4} \text { Perf }_{i q t}+} a_{5} \text { SIZE }_{\text {iqt }}+ \\
& a_{6} \text { CAPITAL }_{i q t}+\alpha_{t}
\end{aligned}
$$


We estimate equation (10) separately for the two measures of bank performance (Perf) namely future operating cash flows $\left(C F_{i q t+\tau}\right)$ and operating earnings $\left(O P_{i q t+\tau}\right)$ over each of the three quarterly time period horizons, from quarter $q t$ to quarter $q t+\tau$, where $\tau=1,2,3$. Thus, $C F_{i q t+\tau}$ is operating cash flows for bank $i$ at $\tau=1, \tau=2$ and $\tau=3$ quarters ahead. Operating cash flows denote the net cash flows arising from operating activities and include interest received, fees and commissions received, and other income received in the ordinary course of bank business, less interest paid, cash paid to suppliers and employees and other expenses incurred in the ordinary course of business. $O P_{i q t+\tau}$ is operating earnings for bank $i$, at $\tau=1, \tau=2$ and $\tau=3$ quarters ahead. Earnings is the banks' net profit before taxes, which is the total interest and non-interest income, less total interest and non-interest expenses, less provision for loan losses. LINFVA, L2NFVA and L3NFVA are the aggregates, at each of the three SFAS 157 classification levels, of a bank's net levels-classified bank fair value assets, (that is, the fair value of assets less liabilities. L1NFVA represents the aggregate of the level 1 fair value assets and liabilities; L2NFVA represents the aggregate of the level 2 fair value assets and liabilities, and $L 3 N F V A$ is the aggregate of the level 3 fair value assets and liabilities.

We include bank size (SIZE), measured by total assets, as a control in the regressions as it influences the magnitude of the future cash flows and earnings generated by banks (Evans et al., 2014). We also include the tier 1 capital ratio $^{6}$ (CAPITAL) as a control in the regressions. This ratio reflects the impact of leverage/capital adequacy and other financial risk factors on banks. Finally, we control for individual year and firm effects in our regressions. ${ }^{7}$

\footnotetext{
${ }^{6}$ Tier 1 capital ratio refers to banks' core capital (equity capital and disclosed reserves) divided by banks' risk weighted assets (that is, all assets held by a bank weighted by their credit risk).

${ }^{7}$ To address endogeneity (reverse causality) issues, we use a lag structure in the models i.e. using current fair values, cash flows and earnings to predict future cash flows/ earnings. We use year effects to account for changing macro-economic conditions that may influence cash flows and earnings and the inclusion of the firm effects to account for firm invariant omitted variable bias.
} 
We test Hypothesis 2 by expanding the regression model (10) to include the effect of the GFC:

$$
\begin{aligned}
& \operatorname{Perf}_{\text {iqt }+\tau}=k_{0}+k_{l} G F C+k_{2} L_{1 N F V A_{i q t}}+k_{3} L 2 N F V A_{i q t}+k_{4} L 3 N F V A_{i q t}+ \\
& k_{5} G F C L 1 N F V A_{i q t}+k_{6} G F C L 2 N F V A_{i q t}+k_{7} G F C L 3 N F V A_{i q t}+k_{8} P e r f_{i q t}+k_{9} S I Z E_{i q t}+ \\
& k_{10} C_{A P I T A L_{i q t}}+\lambda_{t}
\end{aligned}
$$

where $G F C$ is an indicator variable equal to one for the years 2008 and 2009 and zero otherwise. The GFCL1NFVA, GFCL2NFVA, and GFCL3NFVA variables are interaction terms between GFC and L1NFVA, L2NFVA, L3NFVA, respectively. The variables, GFC, GFCL1NFVA, GFCL2NFVA and GFCL3NFVA, are included in the regression equation to capture the influence of the financial crisis on performance and the underlying relationships between the net levels-classified bank fair values and the future performance of banks comprising our sample.

All continuous variables were transformed using the inverse hyperbolic sine (that is, inverse sinh) function to address potential issues of heteroscedasticity and to accommodate both positive and negative values (Burbidge, et al., 1988; Møller and Madsen, 2010).

\section{Empirical Results}

\subsection{Descriptive Statistics}

Table 1 provides the descriptive statistics for cash flow and earnings at one quarter ahead horizons, that is, $C F_{q t+1}$ and $O P_{q t+1}$ in both transformed (based on the inverse sinh function) and untransformed forms. ${ }^{8}$ Thus, panel A of Table 1 shows that the average one quarter ahead transformed future operating cash flows $\left(C F_{q t+1}\right)$ across the 13,926 firm-quarters comprising

\footnotetext{
${ }^{8}$ Descriptive statistics were also computed for the two and three quarters ahead future horizons for operating cash flows $\left(\mathrm{CF}_{q t+2}\right.$ and $\left.\mathrm{CF}_{q t+3}\right)$ and earnings $\left(\mathrm{OP}_{q t+2}\right.$ and $\left.\mathrm{OP}_{q t+3}\right)$ but for reasons of constraints on space are untabulated.
} 
our sample is 2.84; whilst the average transformed net level 1 fair value assets (LINFVA) is 1.64. The average transformed net level 2 fair value assets ( $2 N F V A)$ and the average transformed net level 3 fair value assets ( $L 3 N F V A)$ associated with one quarter ahead operating cash flows are 5.98 and 1.35 , respectively. This shows that there is a higher representation of net level 2 fair value assets ( $22 N F V A)$ in our sample as compared to the net level 1 fair value (L1NFVA) and the net level 3 fair value ( $23 N F V A)$ assets comprising our sample. ${ }^{9}$ Similarly, Panel B of Table 1 shows that the average one quarter ahead transformed future operating earnings $\left(O P_{q t+1}\right)$ across the 13,963 firm-quarters comprising our sample is 1.90 ; whilst the average transformed net level 1 fair value assets $(L 1 N F V A)$ is 1.66 . The average transformed net level 2 fair value assets ( $L 2 N F V A)$ and the average transformed net level 3 fair value assets ( $L 3 N F V A)$ associated with one quarter ahead operating earnings are 6.00 and 1.36, respectively.

Note that the median values for the untransformed net levels-classified bank fair values at all three levels across the sample are non-negative, signifying that more than half the bank-year observations in our samples report level 1,2 and 3 financial asset fair values that exceed their levels 1, 2 and 3 financial liability fair values.

TABLE ONE ABOUT HERE

${ }^{9}$ L2NFVA is larger than L1NFVA and L3NFVA because there is a large proportion of bank assets at level 2 , especially loans and advances, that are not actively traded in the market. 
Table 2, Panel A summarises the univariate sample correlation coefficients for the one quarter ahead operating cash flows data whilst Table 2, Panel B summarises the sample correlation coefficients for the one quarter ahead operating earnings data. ${ }^{10}$ The correlation coefficients do not suggest the presence of multicollinearity. To further investigate the likelihood of multicollinearity, we computed variance inflation factors (Vif) and eigenvalue condition indices. In all cases, the variance inflation factors were lower than 10 and the condition indices fall well below the value of 30 , the level at which the stability of the regression procedures are generally regarded as being seriously compromised by collinear independent variables (Coenders and Saez, 2000).

\section{TABLE TWO ABOUT HERE}

\subsection{Multivariate Analyses}

The results of OLS estimation of the regression models (10) and (11) are presented in Tables 3 and 4. Note that the results reflect use of robust standard errors (White, 1980).

TABLE THREE ABOUT HERE

\footnotetext{
${ }^{10}$ Untabulated similar results were obtained for the correlation coefficients for both the two and three quarters ahead operating cash flows and earnings.
} 


\subsubsection{Bank levels-classified quarterly net fair value assets, future quarterly operating cash flows and future operating earnings (Hypotheses 1a and 1b)}

Panel A of Table 3 reports the results of the estimation of the relationship between the levelsclassified net fair value assets and future quarterly operating cash flows over the period from 2008 until 2015. The adjusted R-squared varies between 0.36 and 0.56 across the three horizons. The coefficient on level 1 net fair value assets $(L 1 N F V A)$ in the relationship is not significant at the one quarter ahead horizon but is significant and positive at the two- and three-quarter ahead horizons (with t-statistics $=4.25$ and 3.90 respectively). The coefficient on level 2 net fair value assets (L2NFVA) is significant and positive at one-, two-, and three-quarter ahead operating cash flows (with t-statistics $=6.86,7.48$ and 7.34 for the one-, two-, and three-quarter horizons, respectively). However, the coefficient on level 3 net fair value assets (L3NFVA) is not significant at any of the three horizons. Taken overall, the results suggest that levels classified net asset fair values at levels 1 and 2 have predictive value for banks' future cash flows and thus support Hypothesis 1a for future bank performance as measured by operating cash flows. The results are consistent with the results obtained in Ehalaiye et al (2017).

Comparison of the predictive value of the levels-classified net fair value assets across levels 1 , 2, and 3 indicates that levels 1 and 2 have predictive value and level 3 does not. It also appears that level 2 has a stronger predictive value than does level 1. In terms of statistical significance of the coefficients, this is confirmed by a Wald test. ${ }^{11}$ The results, therefore, support Hypothesis 1b, that there is significant variation, across the SFAS157 levels, in the predictive value of levels-classified net fair value assets for the future performance of banks as measured

\footnotetext{
${ }^{11}$ A Wald test shows that the coefficients on $L 1 N F V A$ and $L 2 N F V A$ are statistically different with $F$-statistics of $18.92,8.20$ and 10.16 (all significant at the $1 \%$ level) for $C F_{q t+1}, C F_{q t+2}$ and $C F_{q t+3}$ respectively.
} 
by cash flows. The result of the comparison of predictive value across levels 1 and 2 is unexpected given that level 1 net fair value assets are based on actual market prices and are, therefore, more objectively determined. However, the descriptive statistics discussed above, show that for our sample of banks the levels-classified net fair value assets are more significant in absolute value terms, at level 2 than at level 1, because the largest proportion of bank net assets - loans and deposits - are not actively traded securities. The result for predictive value at level 3 is expected as net fair value assets at this level are derived from model-based valuations. The inputs to the valuations are as much as possible market-based but the valuations must inevitably have a degree of subjectivity. Our results on the variation across the levels are consistent with Song et al. (2010) who found that the value relevance of level 1 and level 2 net asset fair values were greater than the value relevance of level 3 net asset fair values. However, our results are not consistent with Altamuro and Zhang (2013), particularly when the market for the underlying asset is inactive ${ }^{12}$.

Finally, Panel A of Table 3 shows that among the controls, the coefficient on current quarter cash flow from operations $\left(C F_{q t}\right)$ is significant and positive (with t-statistics $=23.79,15.02$ and 11.75 for the one-, two-, and three- quarter horizons, respectively), which supports persistence of cash flows. Size of total assets is also significant and positive (with t-statistics $=5.77,8.26$ and 9.43 for the one-, two-, and three- quarter horizons, respectively) but the coefficient on the tier 1 capital ratio (CAPITAL) is not significant at any of the three horizons.

Panel B of Table 3 reports the results of estimation for the case of future performance measured by operating earnings. The coefficients on net level 1 net fair value assets (L1NFVA) are not

\footnotetext{
${ }^{12}$ Altamuro and Zhang (2013) argue that this is because of the information advantage that managers have in estimating level 3 inputs. We note that this study focused on a specific asset- MSRs, while our study focuses on the aggregate of all net assets at the various levels-classification of fair values.
} 
significant at any horizon, the coefficients on level 2 net fair value assets (L2NFVA) are significant only at the three-quarter horizon, and the coefficients on level 3 net fair value assets ( $L 3 N F V A)$ are significant at all horizons. However, the significant coefficients are in each case negative. The results are not consistent with Ehalaiye et al (2017) where the results indicated a positive, but weak association between net asset fair values and future performance as measured by earnings. The results are also not consistent with the findings of Bratten et al. (2016) and Yao et al. (2018) which suggest a positive association between current fair values and future earnings. Thus, the results for earnings do not support Hypothesis 1a and likewise by implication, Hypothesis $1 b$.

Thus, the results reported in Panel B of Table 3 on the relationship between the net levels fair value assets and future operating earnings are in contrast with those summarised in Panel A of Table 3 for the relationship between the net levels fair value assets and future operating cash flows. A primary reason for this from a theoretical viewpoint is that fair values represent the expected present value of the future cash flows of net assets rather than the expected present value of their earnings (Ryan, 2008). Additionally, firms' (including banks) earnings are more susceptible to managerial manipulation than are cash flows, especially due to earnings management through discretionary accruals (Shen and Huang, 2011; Morris et al 2016).

\subsubsection{Bank levels-classified quarterly net fair value assets, the GFC years and future performance (Hypothesis 2)}

Panel A of Table 4 shows that for cash flows the coefficient on the GFC dummy variable is not significant at any of the horizons. The results for the coefficients on the levels-classified net asset fair values are qualitatively similar to those obtained without including the GFC dummy in the regressions. The coefficients on the interaction variable GFCL1NFVA are 
significant and positive at the one- and two-quarter horizons and the coefficients on the interaction variable GFCL2NFVA are significant but negative at one-and three-quarter horizons. The coefficients on the interaction variable GFCL3NFVA are not significant at any horizon. Therefore, the effect of the GFC on the association between level 1 net fair value assets and future cash flow is to increase the impact at one- and two-quarter horizons, and on the association between level 2 net fair value assets and future cash flow is to decrease the impact at one- and three-quarter horizons. Overall, the results suggest that for the association between levels-classified net fair value assets and future performance as measured by cash flows, the GFC appears to have had a limited overall impact but with some shift in the relative impact of level 2 to level 1. The results thus provide only limited support for Hypothesis 2 with future performance measured by cash flows. The results are also supported by Figure 1, which shows that during the global financial crisis years of 2008 and 2009 there was an upward trend in the average operating cash flows of the banks comprising our sample, rather than the opposite effect, which might have been expected.

Panel B of Table 4 shows that the coefficient on the GFC dummy variable is significant and negative (with t-statistics of $-2.70,-2.66$ and -3.78 for the one, two and three quarter ahead operating earnings, respectively). This suggests that the GFC had a substantial adverse impact on bank future operating earnings.

The results for the coefficients on the levels-classified net asset fair values are qualitatively different from those obtained without including the GFC dummy in the regressions. In particular, the coefficient on level 2 net fair value assets (L2NFVA) is strongly significant and positive at all three horizons (with t-statistics $=2.24,3.17$, and 2.73 for the one-, two-, and three-quarter horizons, respectively). The coefficients on the interaction variable GFCLINFVA are not significant at any horizon but the coefficients on the interaction variables GFCL2NFVA 
and GFCL3NFVA are significant and negative at all horizons. Therefore, the effect of the GFC on the association between levels-classified net fair value assets and future earnings is to decrease the impact of levels 2 and 3 net fair value assets at all horizons. Overall, the results suggest that the GFC had a strong impact on the association between levels-classified net fair value assets and future earnings. Indeed, the results show that although the results reported in Panel B of Table 3 indicate a weak association between levels-classified net fair value assets and future earnings, assessment of the degree of association needs to allow for the effect of the GFC. Figure 1 also points to the impact of the GFC on earnings with a sharp dip in earnings during the GFC years. It is interesting to note that while earnings dipped, cash flows increased, possibly indicating that the level of write downs taken during the GFC years was higher than warranted by actual experience.

TABLE FOUR ABOUT HERE

FIGURE ONE ABOUT HERE

\subsection{Robustness Analysis}

A limitation of using a short-term future horizon (between 1 and 3 quarters) for our analysis could be that these periods may not adequately capture the impact of current fair values on future bank performance. As such, we replicated our empirical analysis using a six-quarter 
horizon window under which operating cash flows, $C F_{i q t+\tau}$, and operating earnings, $O P_{i q t+\tau}$, for bank $i$ varied from $\tau=1$ up to $\tau=6$ quarters ahead in all regression models. The results (untabulated) showed no qualitative differences from the results reported for the three quarters ahead horizons.

To test for the possible impact of growth on the association between levels-classified net fair value assets and future performance of banks we included a variable for growth measured by the logarithm of bank total assets or net loans at time $t$ divided by bank total assets or net loans at time $(\mathrm{t}-1)$ where time $\mathrm{t}$ represents the particular "quarter" during the study period. The results (untabulated) showed there was no significant impact from the introduction of this variable.

Finally, we replicated our entire empirical analysis using only those banks with available data for all three quarters. Again, there was no qualitative difference between the results (untabulated), and the results reported above.

\section{Discussion and Conclusion}

This paper examines the association between the SFAS 157 levels-classified net fair value assets recognised in banks' financial statements, and the banks' future performance as measured by their operating cash flows and by earnings over a three-quarter future time horizon. The study covers the period from 2008 until 2015 and thereby includes consideration of the impact that the GFC had on the relationship between levels-classified net fair value assets and future bank performance. The empirical results are consistent with a positive association between bank net asset fair values and future bank performance. This holds for level 1 and level 2 net fair value assets and future operating cash flows. The relationship also holds for 
level 2 net fair value assets and earnings but only if the relationship includes the effect of the GFC. The stronger predictive value of levels-classified net fair values for cash flows than for earnings is consistent with the theoretical notion of fair values as representing the present value of future cash flows rather than earnings and also the recognition of management's ability to manipulate earnings using discretionary accruals (Ryan, 2008; Morris, et al., 2016; Shahzad, et al., 2019). The results show that communication in financial statements of information on fair value is consistent with the FASB (2010:17) view that asset values shown in firm's financial statements should communicate information about the potential future performance of the affected firms.

The results also show significant variation across the SFAS 157 levels, in the predictive value of levels-classified net fair value assets for future cash flows and earnings of banks. This suggests that the levels classification brought about by SFAS 157 is important when considering the value relevance of bank fair values and supports the view of Barth (2006) and Tweedie (2008), amongst others. Interestingly, the level 2 fair values rather than level 1 fair values provide the strongest predictive value for future bank performance. This contrasts with existing literature that uses the value relevance models based on share prices, which show that level 1 fair values have greater value relevance than level 2 (Song, et al., 2010; Goh, et al., 2015). However, consistent with the existing literature, our results show that aggregate net level 3 asset fair values are not good at predicting future cash flows or earnings of banks.

Our results are consistent with the results obtained in Ehalaiye et al (2017) which were based on annual amounts disclosed in the notes to the financial statements. The study thus provides support for questioning the need for more frequent reporting than annually. Furthermore, and more importantly, the study also fills a significant gap in the recognition versus disclosure literature by evaluating the predictive value of the levels-classified fair values recognised in 
the banks' financial statements in contrast to the supplementary note disclosures of fair values mandated by SFAS 107 (Barth, Clinch and Shibano, 2003; Bratten, Choudhary and Schipper, 2013). The results suggest that in terms of the predictive value of net fair value assets for cash flows and earnings of banks, that the two forms of reporting information are equally effective. We find that the GFC years did not have a negative impact on bank future operating cash flows. However, the GFC years did have a marginal but not compelling impact on the underlying relationship between the bank levels-classified net fair value assets (in particular levels 1 and 2 fair values) and their future operating cash flows. This finding is relevant to the debate about the influence of market illiquidity on the quality of the fair values recognised by banks, because if as a result of an illiquid market, the fair values recognised in the banks' financial statements are not reliable, such recognised values should have no predictive value.

In contrast, we provide strong evidence that the GFC had a significant adverse impact on future operating earnings and that with allowance for the effect of the GFC, the level 2 net fair value assets have predictive value for the future earnings of banks. The negative impact of the GFC on earnings suggests that whilst banks implemented significant asset write-downs, which adversely affected their operating earnings over the GFC, they were, at the same time, building up their operating cash flows. These findings contrast with the acrimonious debate over the implementation of fair value accounting during the GFC where it was alleged that fair value accounting deepened an already chronic liquidity crisis by inducing banks to engage in a fire sale of their assets to meet regulatory capital requirements.

Our results have important regulatory and policy implications, as well as limitations. Firstly, in terms of assisting policy makers, regulators and accounting standards setters such as the SEC, FASB, and IASB, the study findings imply that fair value-based general purpose financial reporting can communicate firms' future financial performance, especially in terms of cash 
flows. Further, from the study findings, it is clear that the more objectively defined fair values at levels 1 and 2 do have a better predictive capacity for performance than do the level 3 modelbased fair values. The implication of this is for banks to focus their efforts more on the reporting of level 1 and 2 fair values rather than level 3 fair values.

Although our findings are robust and important, we acknowledge some limitations of our study, particularly, that future cash flows and earnings may not capture the unobservable discount rate of future cash flows that share prices are assumed to reflect in standard value relevance analysis (Ohlson 1995; Isaboke and Chen, 2019; Jermakowicz, Chen and Donker, 2018). Also, we note that 3 quarter future horizons may be too short to reflect the effects of current fair values on future cash flows and earnings. Although we robustly test for a longer window using up to 6 quarter horizons in our analysis, it is possible that current fair values may not reflect future performance during these periods. In terms of future research, studies could explore the role of governance in the determination of the levels' classification of reported bank fair values and whether such governance mechanisms impact the performance prediction value of levelsclassified fair values. 


\section{References}

Aboody, D., Barth, M. E., \& Kasznik, R. (1999). Revaluations of fixed assets and future firm performance: Evidence from the U.K. Journal of Accounting and Economics, 26(1), 149-178.

Altamuro, J., \& Zhang, H. (2013). The financial reporting of fair value based on managerial inputs versus market inputs: Evidence from mortgage servicing rights. Review of Accounting Studies, 18(3), 833-858.

American Bankers Association (2008). Letter to SEC. September 23, 2008.

Barth, M. E. (2006). Including estimates of the future in today's financial statements. Accounting Horizons, 20(3), 271-285.

Barth, M. E., Clinch, G., \& Shibano, T. (2003). Market effects of recognition and disclosure. Journal of Accounting research, 41(4), 581-609.

Beaver, W.H (1998). Financial Reporting: An Accounting Revolution. Englewood Cliffs, New Jersey: Prentice-Hall

Benston, G. J. (2008). The shortcomings of fair-value accounting described in SFAS 157. Journal of Accounting and Public Policy, 27(2), 101-114.

Bernard, V. L. (1993). Discussion of an investigation of revaluations of tangible long-lived assets. Journal of Accounting Research, 31, 39-45.

Bratten, B., Causholli, M., \& Khan, U. (2016). Usefulness of fair values for predicting banks' future earnings: evidence from other comprehensive income and its components. Review of Accounting Studies, 21(1), 280-315.

Bratten, B., Choudhary, P., \& Schipper, K. (2013). Evidence that market participants assess recognized and disclosed items similarly when reliability is not an issue. The Accounting Review, 88(4), 1179-1210.

Brunnermeier, M. K. (2009). Deciphering the liquidity and credit crunch 2007-2008. Journal of Economic Perspectives, 23(1), 77-100.

Burbidge, J., Magee, L., \& Robb, A. (1988). Alternative transformations to handle extreme values of the dependent variable. Journal of the American Statistical Association, 83(401), 123-127.

Coenders, G., \& Saez, M. (2000). Collinearity, heteroscedasticity and outlier diagnostics in regression. Do they always offer what they claim? New Approaches in Applied Statistics, 16, $79-94$.

Dechow, P. M., Kothari, S. P., \& Watts, R. (1998). The relation between earnings and cash flows. Journal of Accounting and Economics, 25(2), 133-168.

Eccher, E. A., Ramesh, K., \& Thiagarajan, S. R. (1996). Fair value disclosures by bank holding companies. Journal of Accounting and Economics, 22(1-3), 79-117.

Ehalaiye, D., Tippett, M., \& van Zijl, T. (2017). The Predictive Value of Bank Fair Values. Pacific-Basin Finance Journal, 41(February), 111-127. 
Evans, M. E., Hodder, L., \& Hopkins, P. E. (2014). The Predictive Ability of Fair Values for Future Financial Performance of Commercial Banks and the Relation of Predictive Ability to Banks' Share Prices. Contemporary Accounting Research, 31(1), 3-44.

Financial Accounting Standards Board (2006). "Fair Value Measurements"; Statement of Financial Accounting Standards No. 157, Norwalk; CT: FASB.

Financial Accounting Standards Board (2008). "Determining the Fair Value of a Financial Asset when the Market for That Asset is Not Active"; FASB Staff Position, FSP FAS 157-3, October 10.

Financial Accounting Standards Board (2009). "Determining Fair Value When the Volume and Level of Activity for the Asset or Liability Have Significantly Decreased and Identifying Transactions that are not orderly". FASB Staff Position, FSP FAS 157-4, April 9.

Financial Accounting Standards Board (2010). "Conceptual Framework of Financial Reporting"; Statement of Financial Accounting Concepts No. 8, Norwalk: CT: FASB.

Fox, J. (1991). Regression diagnostics: An introduction .U.S.A: Sage.

Goh, B. W., Li, D., Ng, J., \& Yong, K. O. (2015). Market pricing of banks' fair value assets reported under SFAS 157 since the 2008 financial crisis. Journal of Accounting and Public Policy, 34(2), 129-145.

Houqe, N. (2018). A review of the current debate on the determinants and consequences of mandatory IFRS adoption. International Journal of Accounting \& Information Management. 26(3), 413-442.

Isaboke, C., \& Chen, Y. (2019). IFRS adoption, value relevance and conditional conservatism: evidence from China. International Journal of Accounting \& Information Management. 27(4), 529-546.

Jermakowicz, E. K., Chen, C. D., \& Donker, H. (2018). Financial statement effects of adopting IFRS: the Canadian experience. International Journal of Accounting \& Information Management. 26(4), 466-491.

Leone, M. (2008). "Bankers: Fair Value is like throwing gasoline on a fire". Available at: www.cfo.com; April 14, 2008.

Liu, C. (2011). IFRS and US-GAAP comparability before release No. 33-8879. International Journal of Accounting \& Information Management. 19(1), 24-33.

Modigliani, F. \& Miller, M. (1958). The cost of capital, corporation finance and the theory of investment. American Economic Review, 48(3): 261-297.

Møller, J. K. \& Madsen, H. (2010). From State Dependent Diffusion to Constant Diffusion in Stochastic Differential Equations by the Lamperti Transform. Kgs. Lyngby, Denmark: Technical University of Denmark, DTU Informatics, Building 321. (IMM-Technical Report2010-16).

Morris, R. D., Kang, H., \& Jie, J. (2016). The determinants and value relevance of banks' discretionary loan loss provisions during the financial crisis. Journal of Contemporary Accounting \& Economics, 12(2), 176-190. 
Ohlson, J. A. (1995). Earnings, book values, and dividends in equity valuation. Contemporary accounting research, 11(2), 661-687.

Penman, S. H. (2007). Financial reporting quality: is fair value a plus or a minus?. Accounting and business research, 37(sup1), 33-44.

Ryan, S.G. (2008). Fair Value Accounting: Understanding the issues raised by the credit crunch, Council of Institutional Investors, July 2008, 1-24.

Shahzad, F., Rehman, I. U., Hanif, W., Asim, G. A., \& Baig, M. H. (2019). The influence of financial reporting quality and audit quality on investment efficiency. International Journal of Accounting \& Information Management. 27(4), 600-614.

Shen, C. H. \& Huang, Y.L. (2011). Effects of earnings management on bank cost of debt. Accounting \& Finance, 53(1), 265-300.

Song, C, J., Thomas, W.B. \& Han, Y. (2010). Value Relevance of FAS No. 157 Fair Value Hierarchy Information and the Impact of Corporate Governance Mechanisms. The Accounting Review, 85 (4), 1375-1410.

Tweedie, D. (2008). Bringing transparency to financial reporting: towards an improved accounting framework in the aftermath of the credit crisis. Financial Stability Review, Banque de France, No. 12, October, 115-120.

Wallison, P. J. (2008). Fair Value Accounting: A Critique. American Enterprise Institute for Public Policy Research Outlook Series, July 2008.

White, H. (1980). A heteroskedasticity-consistent covariance matrix estimator and a direct test for heteroskedasticity. Econometrica: Journal of the Econometric Society, 48(4), 817-838.

Yao, D., Percy, M., Stewart, J., \& Hu, F. (2018). Fair value accounting and earnings persistence: evidence from international banks. Journal of International Accounting Research, 17(1), 47 68. 
Tables and figure:

Table 1

Descriptive Statistics for the operating cash flow and earnings models

Panel A: Descriptive statistics for regression models for one-quarter ahead operating cash flows

\begin{tabular}{|c|c|c|c|c|c|c|c|c|c|}
\hline \multirow[b]{2}{*}{ Variable } & \multirow[b]{2}{*}{$\begin{array}{c}\text { (Firm- } \\
\text { Quarters) }\end{array}$} & \multicolumn{4}{|c|}{ Transformed variables } & \multicolumn{4}{|c|}{ Untransformed (raw) variables $^{13}$} \\
\hline & & Mean & Std. Dev. & Median & Q3 & Mean & Std. Dev. & Median & Q3 \\
\hline$C F_{q t+1}$ & 13926 & 2.84 & 3.03 & 3.10 & 4.38 & 408.22 & 4506.97 & 11.07 & 39.98 \\
\hline LINFVA & 13926 & 1.64 & 2.52 & 0.25 & 2.69 & 1315.62 & 13153.80 & 0.26 & 7.35 \\
\hline L2NFVA & 13926 & 5.98 & 2.57 & 6.22 & 7.17 & 3446.18 & 25041.70 & 252.02 & 650.83 \\
\hline L3NFVA & 13926 & 1.35 & 2.41 & 0.00 & 2.34 & 366.15 & 3848.30 & 0.00 & 5.14 \\
\hline SIZE & 13926 & 8.68 & 1.71 & 8.14 & 9.26 & 48968.06 & 260000.00 & 1713.38 & 5247.88 \\
\hline CAPITAL & 13926 & 12.50 & 3.92 & 12.20 & 14.26 & 12.50 & 3.92 & 12.20 & 14.26 \\
\hline$C F$ & 13926 & 2.74 & 3.19 & 3.07 & 4.32 & 432.49 & 5443.05 & 10.73 & 37.52 \\
\hline
\end{tabular}

Panel B: Descriptive statistics for regression models for one-quarter ahead operating earnings

\begin{tabular}{|c|c|c|c|c|c|c|c|c|c|}
\hline & & \multicolumn{4}{|c|}{ Transformed variables } & \multicolumn{4}{|c|}{ Untransformed (raw) variables } \\
\hline Variable & $\begin{array}{c}\text { (Firm- } \\
\text { Quarters) }\end{array}$ & Mean & Std. Dev. & Median & Q3 & Mean & Std. Dev. & Median & Q3 \\
\hline$O P_{q t+1}$ & 13963 & 1.90 & 2.74 & 1.90 & 3.33 & 111.87 & 614.06 & 3.28 & 13.95 \\
\hline LINFVA & 13963 & 1.66 & 2.56 & 0.24 & 2.70 & 1368.73 & 13085.13 & 0.25 & 7.40 \\
\hline$L 2 N F V A$ & 13963 & 6.00 & 2.56 & 6.22 & 7.18 & 3696.58 & 25094.59 & 251.76 & 655.17 \\
\hline L3NFVA & 13963 & 1.36 & 2.43 & 0.00 & 2.36 & 364.44 & 3675.25 & 0.00 & 5.27 \\
\hline SIZE & 13963 & 8.70 & 1.74 & 8.14 & 9.28 & 49310.06 & 250000.00 & 1720.06 & 5380.44 \\
\hline CAPITAL & 13963 & 12.50 & 3.82 & 12.21 & 14.26 & 12.50 & 3.82 & 12.21 & 14.26 \\
\hline$O P$ & 13963 & 1.83 & 2.79 & 1.86 & 3.25 & 104.92 & 651.20 & 3.14 & 12.91 \\
\hline
\end{tabular}

13 The descriptive statistics for the untransformed variables are all stated in millions of US dollars except for CAPITAL, which is a ratio. 
Table 2

Correlation Matrices for the Cash flow and earnings models at quarter $q t+1$

Panel A: Correlation Matrix for Cash flows at quarter $q t+1$ (N=13,926 Firm-quarters)

\begin{tabular}{|c|c|c|c|c|c|c|c|}
\hline & $C F_{q t+1}$ & LINFVA & L2NFVA & L3NFVA & $S I Z E$ & CAPITAL & $C F$ \\
\hline$C F_{q t+1}$ & 1 & & & & & & \\
\hline LINFVA & $0.2429 * * *$ & 1 & & & & & \\
\hline L2NFVA & $0.3152 * * *$ & $0.3885 * * *$ & 1 & & & & \\
\hline L3NFVA & $0.2132 * * *$ & $0.4050 * * *$ & $0.3947 * * *$ & 1 & & & \\
\hline SIZE & $0.3101 * * *$ & $0.5102 * * *$ & $0.2647 * * *$ & $0.4612 * * *$ & 1 & & \\
\hline CAPITAL & $0.0200 * *$ & 0.0099 & $0.0890 * * *$ & $-0.0757 * * *$ & $-0.0518 * * *$ & 1 & \\
\hline$C F$ & $0.7251 * * *$ & $0.1989 * * *$ & $0.2671 * * *$ & $0.1693 * * *$ & $0.2577 * * *$ & $0.0288 * * *$ & 1 \\
\hline
\end{tabular}

Panel B: Correlation Matrix for Earnings at quarter $q t+1$ ( $=13,963$ Firm-quarters)

\begin{tabular}{|c|c|c|c|c|c|c|c|}
\hline & $O P_{q t+1}$ & LINFVA & L2NFVA & L3NFVA & SIZE & CAPITAL & $O P$ \\
\hline$O P_{q t+1}$ & 1 & & & & & & \\
\hline$L I N F V A$ & $0.3159 * * *$ & 1 & & & & & \\
\hline L2NFVA & $0.1960 * * *$ & $0.4471 * * *$ & 1 & & & & \\
\hline$L 3 N F V A$ & $0.2258 * * *$ & $0.4242 * * *$ & $0.4246 * * *$ & 1 & & & \\
\hline SIZE & $0.5989 * * *$ & $0.5191 * * *$ & $0.2879 * * *$ & $0.4684 * * *$ & & & \\
\hline CAPITAL & $0.1674 * * *$ & 0.0118 & $0.0927 * * *$ & $-0.0721 * * *$ & $-0.0468 * * *$ & & \\
\hline$O P$ & $0.8719 * * *$ & $0.2934 * * *$ & $0.1844 * * *$ & $0.2069 * * *$ & $0.5574 * * *$ & $0.1667 * * *$ & 1 \\
\hline
\end{tabular}


Table 3

Panel A: Relationship between bank levels-classified net fair value assets and operating cash flows in future quarters $1,2 \& 3$.

\begin{tabular}{|c|c|c|c|c|c|c|c|}
\hline \multirow[b]{2}{*}{ Variable } & \multirow[b]{2}{*}{$\begin{array}{c}\text { Predicted } \\
\text { Sign } \\
\end{array}$} & \multicolumn{2}{|c|}{ One quarter ahead } & \multicolumn{2}{|c|}{ Two quarters ahead } & \multicolumn{2}{|c|}{ Three quarters ahead } \\
\hline & & Coefficient & t-stat & Coefficient & t-stat & Coefficient & t-stat \\
\hline LINFVA & + & 0.0215 & 1.47 & $0.0847 * * *$ & 4.25 & $0.0836 * * *$ & 3.90 \\
\hline$L 2 N F V A$ & + & $0.117 * * *$ & 6.86 & $0.178 * * *$ & 7.48 & $0.198 * * *$ & 7.34 \\
\hline L3NFVA & + & 0.0102 & 0.60 & 0.0293 & 1.39 & 0.0258 & 1.16 \\
\hline SIZE & + & $0.171 * * *$ & 5.77 & $0.370 * * *$ & 8.26 & $0.443 * * *$ & 9.43 \\
\hline CAPITAL & + & -0.00277 & -0.35 & 0.00473 & 0.38 & 0.00641 & 0.43 \\
\hline$C F$ & + & $0.637 * * *$ & 23.79 & $0.401 * * *$ & 15.02 & $0.293 * * *$ & 11.75 \\
\hline Intercept & $?$ & -0.311 & -0.36 & -0.626 & -0.91 & $-1.114 * *$ & -2.04 \\
\hline Year effects & & YES & & YES & & YES & \\
\hline Firm effects & & YES & & YES & & YES & \\
\hline Observations & & 13,926 & & 13,253 & & 12,599 & \\
\hline Adj.R-squared & & 0.56 & & 0.41 & & 0.36 & \\
\hline
\end{tabular}

Panel B: Relationship between bank levels-classified net fair value assets and operating earnings in future quarters $1,2 \& 3$.

\begin{tabular}{|c|c|c|c|c|c|c|c|}
\hline \multirow[b]{2}{*}{ Variable } & \multirow[b]{2}{*}{$\begin{array}{c}\text { Predicted } \\
\text { Sign }\end{array}$} & \multicolumn{2}{|c|}{ One quarter ahead } & \multicolumn{2}{|c|}{ Two quarters ahead } & \multicolumn{2}{|c|}{ Three quarters ahead } \\
\hline & & Coefficient & t-stat & Coefficient & t-stat & Coefficient & t-stat \\
\hline LINFVA & + & 0.00716 & 1.00 & 0.0097 & 1.10 & 0.00915 & 0.93 \\
\hline L2NFVA & + & -0.0061 & -0.73 & 0.00872 & 0.88 & $-0.0167 *$ & -1.77 \\
\hline L3NFVA & + & $-0.0137 * *$ & -2.06 & $-0.0223 * *$ & -2.36 & $-0.0181 *$ & -1.81 \\
\hline SIZE & + & $0.295 * * *$ & 13.82 & $0.336 * * *$ & 14.46 & $0.499 * * *$ & 20.75 \\
\hline CAPITAL & + & $0.0216 * * *$ & 5.10 & $0.0230 * * *$ & 4.52 & $0.0321 * * *$ & 4.71 \\
\hline$O P$ & + & $0.729 * * *$ & 49.16 & $0.675^{* * *}$ & 41.84 & $0.557 * * *$ & 33.08 \\
\hline Intercept & $?$ & $-2.135 * * *$ & -9.88 & $-4.324 * * *$ & -4.57 & $-4.915 * * *$ & -5.95 \\
\hline Year effects & & YES & & YES & & YES & \\
\hline Firm effects & & YES & & YES & & YES & \\
\hline Observations & & 13963 & & 13317 & & 12651 & \\
\hline Adj.R-squared & & 0.79 & & 0.75 & & 0.71 & \\
\hline
\end{tabular}


Table 4

Panel A: Relationship between bank levels-classified net fair value assets and operating cash flows in future quarters $1,2 \& 3$ in conjunction with the 2008-2009 years of the global financial crises.

\begin{tabular}{|c|c|c|c|c|c|c|c|}
\hline \multirow[b]{2}{*}{ Variable } & \multirow[b]{2}{*}{$\begin{array}{c}\text { Predicted } \\
\text { Sign } \\
\end{array}$} & \multicolumn{2}{|c|}{ One quarter ahead } & \multicolumn{2}{|c|}{ Two quarters ahead } & \multicolumn{2}{|c|}{ Three quarters ahead } \\
\hline & & Coefficient & t-stat & Coefficient & t-stat & Coefficient & t-stat \\
\hline$G F C$ & - & 0.13 & 0.93 & 0.0614 & 0.31 & 0.221 & 0.98 \\
\hline LINFVA & + & 0.00452 & 0.26 & $0.0665^{* * *} *$ & 2.91 & $0.0693 * * *$ & 2.95 \\
\hline$L 2 N F V A$ & + & $0.136^{* * *}$ & 6.36 & $0.197 * * *$ & 6.92 & $0.227 * * *$ & 7.10 \\
\hline L3NFVA & + & 0.00445 & 0.24 & 0.0276 & 1.17 & 0.0161 & 0.62 \\
\hline GFCLINFVA & - & $0.0621 * * *$ & 3.06 & $0.0448 *$ & 1.65 & 0.0253 & 0.88 \\
\hline GFCL2NFVA & - & $-0.0520 * *$ & -2.12 & -0.0534 & -1.52 & $-0.0875 * *$ & -2.26 \\
\hline GFCL3NFVA & - & 0.0167 & 0.65 & 0.0219 & 0.61 & 0.0511 & 1.22 \\
\hline SIZE & + & $0.169 * * *$ & 5.64 & $0.392 * * *$ & 8.53 & $0.451 * * *$ & 9.44 \\
\hline CAPITAL & + & -0.00412 & -0.52 & 0.00386 & 0.31 & 0.00404 & 0.27 \\
\hline$C F$ & + & $0.637 * * *$ & 23.92 & $0.384 * * *$ & 14.64 & $0.282 * * *$ & 11.71 \\
\hline Intercept & $?$ & $-1.150 * * *$ & -4.65 & $-2.838 * * *$ & -7.36 & $-3.215 * * *$ & -7.87 \\
\hline Firm effects & & YES & & YES & & YES & \\
\hline Observations & & 13917 & & 13256 & & 12604 & \\
\hline Adj.R-squared & & 0.56 & & 0.40 & & 0.35 & \\
\hline
\end{tabular}

Panel B: Relationship between bank levels-classified net fair value assets and operating earnings in future quarters $1,2 \& 3$ in conjunction with the 2008-2009 years of the global financial crises.

\begin{tabular}{|c|c|c|c|c|c|c|c|}
\hline \multirow[b]{2}{*}{ Variable } & \multirow[b]{2}{*}{$\begin{array}{c}\text { Predicted } \\
\text { Sign }\end{array}$} & \multicolumn{2}{|c|}{ One quarter ahead } & \multicolumn{2}{|c|}{ Two quarters ahead } & \multicolumn{2}{|c|}{ Three quarters ahead } \\
\hline & & Coefficient & t-stat & Coefficient & t-stat & Coefficient & t-stat \\
\hline$G F C$ & - & $-0.196 * * *$ & -2.70 & $-0.259 * * *$ & -2.66 & $-0.473 * * *$ & -3.78 \\
\hline LINFVA & + & -0.00704 & -1.05 & -0.00326 & -0.39 & $-0.0190 *$ & -1.77 \\
\hline$L 2 N F V A$ & + & $0.0180 * *$ & 2.24 & $0.0335^{* * *}$ & 3.17 & $0.0356 * * *$ & 2.73 \\
\hline$L 3 N F V A$ & + & -0.0000147 & -0.00 & 0.00446 & 0.53 & 0.00483 & 0.51 \\
\hline GFCLINFVA & - & 0.0275 & 1.63 & 0.0208 & 0.93 & 0.0193 & 0.66 \\
\hline GFCL2NFVA & - & $-0.0392 * * *$ & -2.67 & $-0.0644 * * *$ & -3.35 & $-0.0633 * * *$ & -2.61 \\
\hline GFCL3NFVA & - & $-0.0724 * * *$ & -3.80 & $-0.0876 * * *$ & -3.27 & $-0.108 * * *$ & -3.16 \\
\hline SIZE & + & $0.288 * * *$ & 15.28 & $0.353 * * *$ & 15.74 & $0.508 * * *$ & 20.84 \\
\hline CAPITAL & + & $0.0229 * * *$ & 5.45 & $0.0276^{* * *}$ & 5.23 & $0.0371 * * *$ & 5.17 \\
\hline$O P$ & + & $0.734 * * *$ & 54.8 & $0.660 * * *$ & 43.9 & $0.544 * * *$ & 31.05 \\
\hline Intercept & $?$ & $-2.217 * * *$ & -14.49 & $-2.712 * * *$ & -14.52 & $-3.833 * * *$ & -17.80 \\
\hline Firm effects & & YES & & YES & & YES & \\
\hline Observations & & 13959 & & 13313 & & 12651 & \\
\hline Adj.R-squared & & 0.79 & & 0.75 & & 0.70 & \\
\hline
\end{tabular}


Figure 1: Operating Cash flows and Earnings of banks from 2004-2015

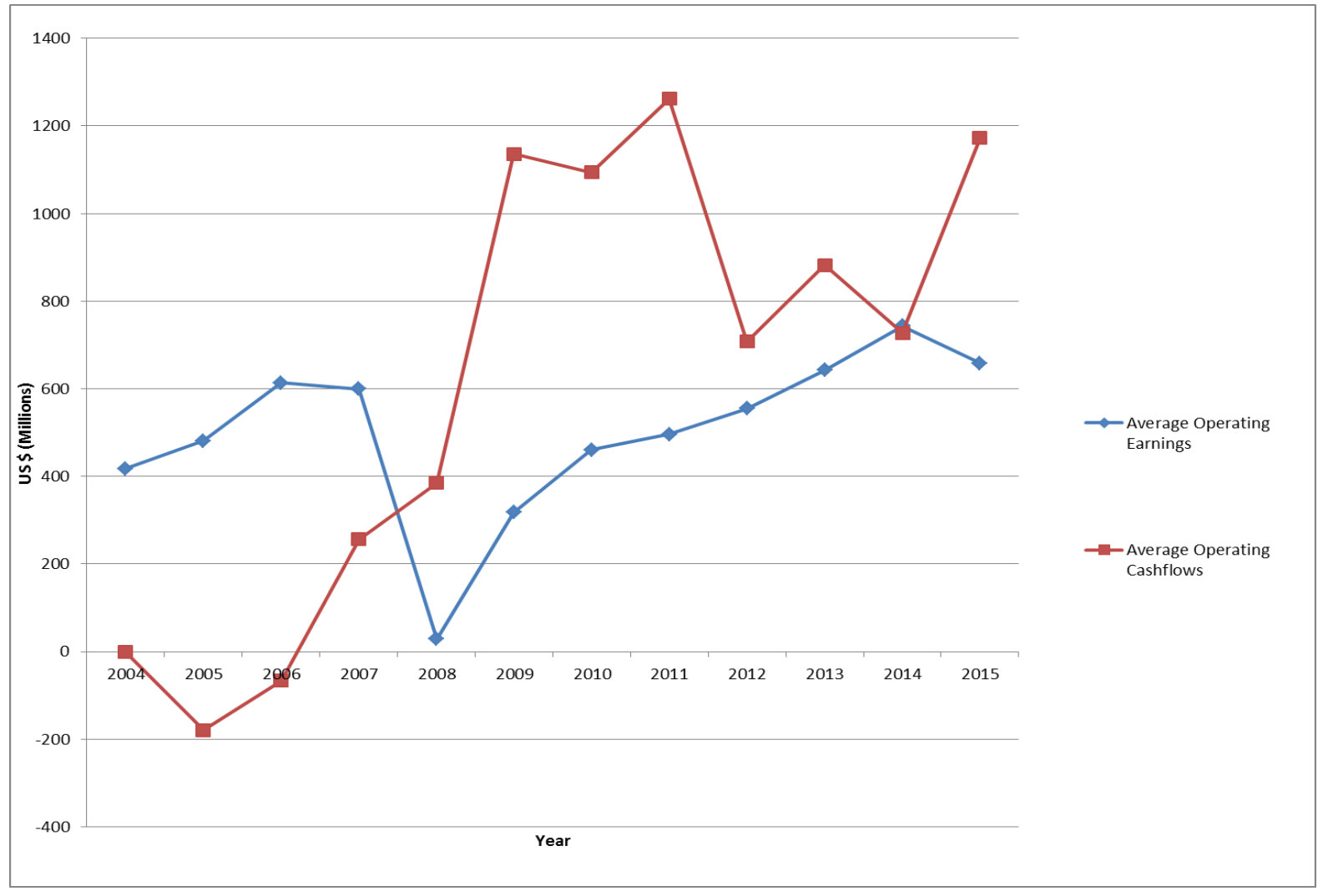




\title{
The impact of SFAS 157 on fair value accounting and future bank performance
}

\author{
Ehalaiye, D
}

2020-10-16

22/04/2023 - Downloaded from MASSEY RESEARCH ONLINE 